Improving Phosphorus Fertility in Tropical Soils through Biological Interventions

\author{
Astrid Oberson, ${ }^{1}$ Else K. Bünemann, ${ }^{2}$ Dennis K. Friesen, ${ }^{3}$ I.M. Rao, ${ }^{4}$ Paul C. Smithson, ${ }^{5}$ \\ Benjamin L. Turner, ${ }^{6}$ and Emmanuel Frossard, ${ }^{1}$ \\ ${ }^{1}$ Institute of Plant Sciences, Swiss Federal Institute of Technology, Zurich, Switzerland \\ ${ }^{2}$ School of Earth and Environmental Sciences, University of Adelaide, Adelaide, Australia \\ Q1 ${ }^{3}$ International Center for the Improvement of Maize and Wheat (CIMMYT) and International \\ Fertilizer Development Center (IFDC), Ethiopia \\ ${ }^{4}$ Tropical Soil Biology and Fertility Institute, International Center for Tropical \\ Q1 Agriculture (CIAT), Colombia \\ Q1 ${ }^{5}$ Berea College, USA \\ ${ }^{6}$ Smithsonian Tropical Research Institute, Panama
}

\title{
CONTENTS
}

37.1 Introduced Pastures and Cropping Systems in Eastern Colombia........................ 532

37.1.1 Measuring and Explaining Differences in Phosphorus

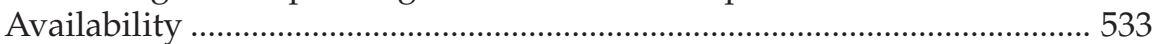

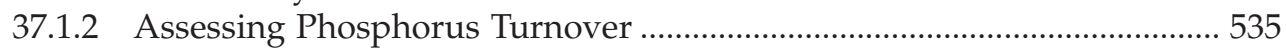

37.1.3 Implications of Experience from Colombia .............................................. 535

37.2 Managed Short-Term Leguminous Fallows in Western Kenya............................ 536

37.2.1 Planted Fallow Alternatives in the Crop Rotation .....................................537

37.2.2 Soil Microbial Involvement in Crop-Fallow Systems ............................... 537

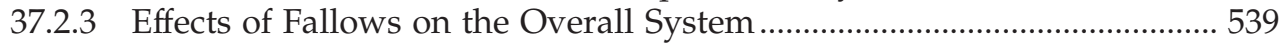

37.2.4 Implications of Experience from Western Kenya ....................................... 540

37.3 Some Further Examples of Improved Soil Phosphorus Availability

by Enhancing Soil Biological Activity..................................................................... 540

37.4 Assessing and Improving Phosphorus Fertility in Tropical Soils ........................ 541

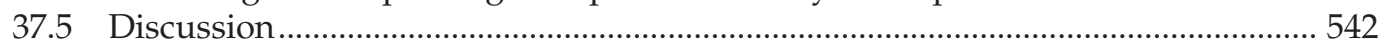

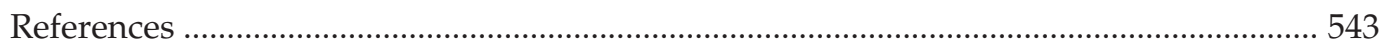

Low availability of phosphorus is a major constraint on agricultural productivity in highly weathered tropical soils. Such soils have a significant capacity to sorb large amounts of phosphorus, taking them out of the soil solution. This limits the availability of inorganic phosphorus for plants, whether it is already contained in the soil or added as fertilizer. Further, some tropical soils contain only small amounts of total phosphorus, with a relatively large proportion of this present in organic forms. This makes biological 
processes vitally important for enhancing phosphorus availability to crops in tropical soils, especially those that are receiving organic amendments as their major nutrient source (Nziguheba and Bünemann, 2005; Oberson and Joner, 2005).

Soil microbes play a central role in enhancing phosphorus availability to plants because they mediate the turnover of phosphorus contained in organic amendments and in soil organic matter. At the same time, the incorporation of phosphorus into microbial cells prevents its strong sorption to soil constituents, thereby maintaining it in a form that can be released subsequently into the soil solution following microbial turnover. Microbial processes are driven by the availability of decomposable organic carbon, which highlights the importance of sustaining and improving soil organic matter concentrations if large populations of microbes are to be active in the soil.

Organic amendments such as manures and plant residues are a major source of organic carbon to the soil. Plants also promote microbial populations and subsequent turnover by exuding organic carbon from their roots (Merckx et al., 1985). Some plants are welladapted to low phosphorus availability owing to their rooting pattern and root characteristics (Rao et al., 1996), their associations with mycorrhizal fungi (Sieverding, 1991), and/or their ability to take up soil phosphorus from recalcitrant compounds (George et al., 2002b). When the selection and breeding of germplasm is adapted for these traits, plants can further enhance the biological cycling of soil phosphorus.

Biological processes that enhance soil phosphorus availability are discussed in detail in Chapter 13, detailing the turnover of phosphorus through the microbial biomass. Such processes can be difficult to assess because they are subject to subtle and complex interactions with various other processes. It is also difficult to synchronize nutrient release by microbial processes with plant demand, an issue that requires further study. Consequently, it is difficult to make broad predictions or generalizations about the impact that biological improvements will have on soil nutrient availability. However, there is sufficient evidence of positive effects in field trials from a variety of agroecosystems that such practices merit serious consideration, even if the scientific basis for understanding the whole process is incomplete.

In this chapter we report on cases where improvements in soil phosphorus availability and turnover were achieved by enhancing soil biological activity. We focus on examples from Colombia and Kenya that combined organic matter management with the use of adapted germplasm and strategic inputs of low doses of phosphorus fertilizers to raise crop productivity and enhance soil fertility. Several additional examples of similar improvements using different biological interventions are considered briefly in the third section.

\subsection{Introduced Pastures and Cropping Systems in Eastern Colombia}

The eastern plains of Colombia include 17 million ha of land dominated by acidic, nutrient-poor Oxisols with a well-defined dry season of 3 to 4 months. The herbaceous native savanna vegetation is of low nutritional value and is used traditionally for extensive beef production. The introduction into pastures of exotic tropical grasses that are adapted to acidic soils, mostly Brachiaria spp., either alone or in conjunction with tropical forage legumes, can increase the productivity of the grazing animals by between 10- and 15-fold (Lascano and Estrada, 1989).

After cultivars adapted to acidic soils were identified by testing, new alternatives for agricultural production were introduced into the area. A major soil chemical constraint on agricultural productivity on the Colombian savannas is the low concentration of total and plant-available phosphorus (Friesen et al., 1997). To understand and improve the efficiency 
of phosphorus use and cycling in production systems in this region, a series of field evaluations was undertaken in the eastern plains of Colombia to assess the interactions among soil phosphorus status (including organic phosphorus), the introduction of pastures or different cropping systems, and microbial phosphorus turnover (Rao et al., 2004). Data from these studies are presented in Table 37.1.

\subsubsection{Measuring and Explaining Differences in Phosphorus Availability}

Improved pastures with new grass species yielded a remarkable increase in beef production with only modest inputs of mineral phosphate fertilizer. This indicated that the efficiency of fertilization was greater than expected on these soils that otherwise strongly sorbed phosphorus. To understand the effect of introduced pastures on phosphorus cycling and availability, phosphorus budgets were estimated, and soil phosphorus status was characterized for soils from (a) unfertilized native savanna pastures, or (b) fertilized, introduced pastures. The latter were either (b1) grass-only (Brachiaria decumbens cv. Basilisk) or (b2) a grass-legume mixture (B. decumbens with Pueraria phaseoloides, commonly known as kudzu) (Oberson et al., 1999).

The activity of soil phosphatase enzymes and the amount of phosphorus in the soil microbial biomass were found to be greater in grass-legume than in grass-only or native savanna pastures. Seasonal analysis of soil phosphorus indicated that the grass-legume system maintained greater concentrations of organic and plant-available phosphorus with less temporal variation than in the two other systems. Analysis of the phosphorus associated with humic and fulvic acids by solution ${ }^{31} \mathrm{P}$ nuclear magnetic resonance spectroscopy revealed in the grass-legume soils greater reserves of phosphate diesters (Guggenberger et al., 1996), which are usually assumed to contribute substantially to plant nutrition (see Chapter 13). Thus the improvement in soil phosphorus availability, as determined by several methods, was clearly greater in grass-legume than in grass-only pastures (Oberson et al., 1999). What could be the reasons for this?

The improved phosphorus availability in grass-legume pastures was not due to differences in fertilizer inputs or exports from the system; alternatively, it could be attributed to changes in the overall biological activity in the soil-plant system caused by the presence of legumes in the vegetation cover. Total carbon and organic phosphorus concentrations (Oberson et al., 1999) as well as macrofaunal activity (Decaens et al., 1994) were all found to be significantly greater in grass-legume soils. Roots from legumes decomposed faster than the roots from Brachiaria grasses (Gijsman et al., 1997a), and annual root production, in terms of both biomass and length, was measured to be significantly greater in the introduced pastures (grass-only and grass-legume) compared with native pasture (Rao et al., 2001).

Mean aboveground litter production in the introduced pastures during the wet season was about $40 \mathrm{~g} \mathrm{~m}^{-2}$ month $^{-1}$ (Thomas et al., 1993). Greater pasture productivity with legumes, associated with greater inputs of plant litter and excrement from the grazing animals in grass-legume pastures, probably provided more consistent organic phosphorus inputs and greater phosphorus cycling and availability, which was in agreement with the results of a simulation of the nitrogen cycle in grass-legume vs. grass-only pastures (Thomas, 1992).

The increased activity of macrofauna in the introduced pastures interacted positively with the increased phosphorus cycling, since total phosphorus was markedly higher in earthworm casts than in the surrounding soil (Jiménez et al., 2003). Increases in microbial phosphorus and plant-available phosphate in the casts were even more pronounced. This suggested that greater concentrations of labile organic phosphorus in pasture soils were linked to a greater abundance of earthworms. Levels of labile organic phosphorus, 
TABLE 37.1

Characteristics of Colombian Oxisols Evaluated

\begin{tabular}{|c|c|c|c|c|c|c|c|c|c|c|}
\hline \multirow[b]{2}{*}{$\begin{array}{l}\text { Location and } \\
\text { Grassland Type }\end{array}$} & \multirow[b]{2}{*}{$\begin{array}{c}\text { Soil Type and } \\
\text { Texture }\end{array}$} & \multirow[b]{2}{*}{$\begin{array}{l}\text { Depth } \\
\text { (cm) }\end{array}$} & \multirow[b]{2}{*}{$\mathrm{pH}$} & \multirow[b]{2}{*}{$\begin{array}{l}\text { Organic C } \\
\left(\mathrm{g} \mathrm{kg}^{-1}\right)\end{array}$} & \multirow[b]{2}{*}{$\begin{array}{c}\text { Total P } \\
\left(\mathrm{mg} \mathrm{kg}^{-1}\right)\end{array}$} & \multirow[b]{2}{*}{$\begin{array}{l}\text { Organic P } \\
\left(\mathrm{mg} \mathrm{kg}^{-1}\right)\end{array}$} & \multirow[b]{2}{*}{$\begin{array}{l}\text { Microbial } \mathrm{P}^{\mathrm{a}} \\
\left(\mathrm{mg} \mathrm{kg}^{-1}\right)\end{array}$} & \multicolumn{2}{|c|}{$\begin{array}{l}\text { Plant-Available P } \\
\quad\left(\mathrm{mg} \mathrm{kg}^{-1}\right)\end{array}$} & \multirow[b]{2}{*}{ Reference } \\
\hline & & & & & & & & (Bray-II) & Resin-extractable P & \\
\hline \multicolumn{11}{|l|}{$\begin{array}{l}\text { Introduced pastures } \\
\text { replacing native savanna }\end{array}$} \\
\hline Native savanna & Oxisol: & $0-10$ & 4.8 & 23.5 & 179 & 64 & 5.2 & 1.3 & 3.5 & \\
\hline Grass-only & $39 \%$ clay, & & 4.85 & 23.2 & 228 & 68 & 5.9 & 1.4 & 4.0 & Oberson et al. (1999) \\
\hline Grass-legume & $19 \%$ sand & & 4.96 & 24.9 & 226 & 77 & 7.3 & 2.2 & 5.2 & \\
\hline \multicolumn{11}{|l|}{$\begin{array}{l}\text { Rice-pasture rotations and } \\
\text { rice monocrop replacing } \\
\text { native savanna }\end{array}$} \\
\hline Native savanna & Oxisol: & $0-10$ & 4.7 & 26.5 & 178 & 85 & 3.9 & 5.7 & 2.1 & Gijsman et al. (1997b) \\
\hline Rice-grass-legume & $40 \%$ clay, & & 4.8 & 31.7 & 209 & 81 & 5.2 & 7.8 & 3.0 & \\
\hline Rice-only & $30 \%$ sand & & 4.7 & 29.2 & 221 & 95 & 4.6 & 6.4 & 3.1 & A. Oberson (unpublished) \\
\hline Rice-grass-legume-rice & & & 4.6 & 27.5 & 250 & 101 & 5.2 & 21.2 & 8.3 & \\
\hline Rice-grass-rice & & & 4.6 & 30.7 & 255 & 95 & 5.4 & 23.5 & 9.4 & \\
\hline Continuous rice & & & 4.8 & 26.8 & 307 & 107 & 3.8 & 32.2 & 11.0 & \\
\hline \multicolumn{11}{|l|}{$\begin{array}{l}\text { Bulk soil and earthworm casts } \\
\text { from native savanna and } \\
\text { grass-legume pasture }\end{array}$} \\
\hline Native savanna & Oxisol: & & & & & & & & & Jiménez et al. (2003) \\
\hline Soil & $39 \%$ clay, & $0-15$ & 5.1 & 21 & 179 & 73 & 2.5 & 1.0 & 0.8 & \\
\hline \multirow{2}{*}{\multicolumn{11}{|c|}{ Grass-legume }} \\
\hline & & & & & & & & & & \\
\hline Soil & & $0-15$ & 5.2 & 21 & 194 & 62 & 4.1 & 2.5 & 1.4 & \\
\hline Casts & & Surface & 5.8 & 52 & 396 & 136 & 10.9 & 11.0 & 12.8 & \\
\hline \multicolumn{11}{|c|}{$\begin{array}{l}\text { Introduced pastures and } \\
\quad \text { rice replacing native savanna }\end{array}$} \\
\hline Savanna & Oxisol: & $0-10$ & 4.9 & 26.1 & 216 & 82 & 5.4 & 1.4 & 2.6 & Oberson et al. (2001) \\
\hline Grass-legume & silty clay & & 4.8 & 28.4 & 272 & 98 & 6.6 & 3.4 & 4.8 & \\
\hline Continuous rice & & & 4.7 & 24.7 & 354 & 98 & 2.6 & 15.6 & 14.3 & \\
\hline
\end{tabular}

a All values present microbial phosphorus extracted after soil fumigation (i.e., no conversion factors $\left(k_{\mathrm{P}}\right)$ applied).

b Same site as in Oberson et al. (1999). 
including phosphate diesters such as DNA, were found to be enriched in earthworm casts (Guggenberger et al., 1996), which could in turn be linked to the greater phosphorus availability in pasture soils.

Earthworms, which play a fundamental role in promoting soil nutrient availability (Jiménez and Decaens, 2004), can be greatly influenced by changes in land use (Decaens et al., 1994). Since earthworm species differ in their nutritional behavior and inhabit different soil layers, the composition of the earthworm community will affect the impact that these organisms have on phosphorus availability. For instance, there is greater phosphate availability in earthworm casts of the geophagous earthworm Pontoscolex corethrurus compared with the bulk soil of an Oxisol, which can be attributed to a combination of selective ingestion of small particles and the partial mineralization of organic phosphorus (Chapuis-Lardy et al., 1998).

The endogeic earthworm, Polypheretima elongate, on the other hand, has been found to increase phosphorus availability by digestive and microbial processes during gut transit (Brossard et al., 1996). However, in both cases, total phosphorus content did not differ between earthworm casts and bulk soil. Still different, the anecic species, Martiodrilus carimaguensis, increases available and total phosphorus content in its casts compared with that in the bulk soil, presumably through the ingestion of phosphorus from plant residues or other organic sources (Jiménez et al., 2003). Earthworms play critical roles within soil food webs and in improving soil physical structure, as discussed in Chapters 5 and 11.

\subsubsection{Assessing Phosphorus Turnover}

The beneficial effect that tropical pastures have on phosphorus cycling through the microbial biomass was evident when rice-pasture rotations replaced native savanna (Gijsman et al., 1997b). Microbial phosphorus, when measured, was lower under monocropped rice and savanna soils than in crop-pasture rotations. In the latter, the activity of the microbial biomass increased in parallel with the overall improvement in soil fertility.

The relationship between microbial phosphorus cycling and the dynamics of extractable organic phosphorus fractions has been studied by Oberson et al. (2001), Bühler et al. (2002). Grass-legume pastures with greater soil organic phosphorus concentrations were associated with greater soil biological activity than under native savanna or soils cropped continuously with rice. Isotopic labeling indicated a rapid microbial phosphorus turnover that was greatest in grass-legume soils. Phosphorus mineralization rates appeared to be greater in grass-legume than in continuous-rice soils, suggesting that the former had a greater potential to render organic phosphorus available to plants (Oberson et al., 2001).

Studies using radio-labeled phosphate have documented the rapid turnover of phosphorus through both the inorganic and organic pools. In one example, a significant proportion of radio-labeled phosphate was recovered in organic phosphorus fractions 2 weeks after labeling, demonstrating that the dynamics of organic phosphorus are important when soil phosphate availability is limited (Bühler et al., 2002). Isotopic labeling has also shown that phosphorus flowed rapidly through, but did not accumulate in, organic phosphorus pools, at least in the short term (Rao et al., 2004). In an experiment with crop rotation and ley pasture, chemical fractionation of soil phosphorus indicated that applied phosphorus fertilizer moved preferentially into labile phosphate pools and then slowly, via biomass production and microbes, into organic phosphorus pools (Friesen et al., 1997).

\subsubsection{Implications of Experience from Colombia}

Overall, the results obtained on low-phosphorus, acidic soils in the eastern plains of Colombia have demonstrated that the combined use of improved germplasm and modest, 
strategic inputs of fertilizer resulted in significantly increased performance of both pastoral and arable production systems, provided that application to arable systems is combined with appropriate tillage and crop rotations (Phiri et al., 2003). The increase in system performance, whether in terms of livestock or crop yields, was clearly related to enhanced soil biological activity and microbial phosphorus turnover.

However, the widespread adoption of agropastoral systems by farmers requires some investment in germplasm and fertilizers as well as knowledge of pasture and crop management techniques. These investments, which occur in conjunction with an intensification and diversification of the overall farm operations, are likely to be made only when remunerative markets for the products are accessible. In the Colombian llanos, local institutions and the Colombian government have restricted their activities and investments, mainly because of social insecurity (Guimaráes et al., 2004). Even though the infrastructure is insufficient there, official efforts continue to make this region more productive and its residents better off.

\subsection{Managed Short-Term Leguminous Fallows in Western Kenya}

Soils in the West Kenyan highlands are predominantly fine-textured, phosphorus-sorbing Oxisols and Alfisols. The rural population there, with 500 to 1200 people $\mathrm{km}^{-2}$, is one of the densest in the world. In the traditional system of shifting cultivation, cropping periods of 1 to 4 years duration were alternated with fallow periods of up to 15 years. This allowed restoration of soil organic matter by above- and belowground biomass production of woody secondary vegetation. However, the duration of fallow periods has now declined to only one to two growing seasons, i.e., one half to one year, due to the high population density and scarcity of arable land. The biomass production of short, weedy fallows is usually insufficient to replenish soil organic matter lost during the cropping period. Many farmers do not fallow their land at all, or only infrequently, with the poorest farmers who have the least amount of land doing the least fallowing if any. This leads to the further impoverishment of both their soils and themselves.

Depletion of soil organic matter leads to a corresponding depletion of nutrients, in part, because mineral fertilizers are too expensive for the rural poor. To address the need to enhance soil system fertility among poor farmers, the World Agroforestry Centre (ICRAF) has developed crop rotations that include more productive fallows, often involving planted legumes, which restore soil fertility and organic matter (Sanchez, 1999). Results of this research program are reported from Zambia and some other countries in Chapter 19 under the rubric of "fertilizer trees." Here, we examine one application of this concept with particular interest in phosphorus mobilization.

Leguminous fallow plants can fix significant amounts of nitrogen from the atmosphere, although the proportion of fixed nitrogen that builds up in plant biomass as well as the total amount of fixed nitrogen will vary according to the species. Gathumbi et al. (2002) reported that in the absence of phosphorus and potassium limitation, the proportions of total plant nitrogen that were fixed from atmospheric nitrogen ranged between 35 and $83 \%$, with the amount of fixed nitrogen being between 8 and $140 \mathrm{~kg} \mathrm{ha}^{-1}$. Of the seven leguminous species studied, Crotalaria grahamiana yielded the highest values of fixed nitrogen. The leguminous fallow tree Sesbania sesban is particularly effective in obtaining nitrogen from the subsoil (Hartemink et al., 1996).

However, despite its overall importance, nitrogen may not be the most limiting nutrient in many situations. On many soils in western Kenya, phosphorus availability is the main 
constraint, as seen from the fact that nitrogen fertilization without the simultaneous addition of phosphorus often fails to increase maize yields (Jama et al., 1997). Even in the absence of external phosphorus inputs, annual maize yields were significantly higher in maize-legume fallow rotations than in continuous maize or maize-natural fallow rotations (Niang et al., 2002; Smestad et al., 2002). This suggests that phosphorus availability was enhanced by alternation with a legume fallow. Secondary effects of fallows on maize growth, e.g., modified soil moisture conditions, may also play a role.

\subsubsection{Planted Fallow Alternatives in the Crop Rotation}

We consider here data on the effects of a leguminous fallow on soil phosphorus dynamics from a case study that lasted 5.5 years (Bünemann, 2003) (Table 37.2). It investigated the relationships among organic matter inputs made through the fallow plant C. grahamiana, soil microbial activity, phosphorus availability, and maize crop performance (Bünemann et al., 2004b). The field experiment, established on an Oxisol, included three maize-based rotations (continuous maize, maize-Crotalaria fallow, and maize-natural fallow rotation) with two levels of phosphorus fertilization $\left(0\right.$ and $50 \mathrm{~kg} \mathrm{P} \mathrm{ha}^{-1}$, applied as triple superphosphate). The maize in each rotation was grown during the long rainy season lasting from March to August. The fallows were maintained in the rotations during the short rainy season lasting from September to February, while in the continuous maize system a second maize crop was planted during the short rains.

Seasonal grain yield in the continuous maize system without phosphorus fertilization was low, varying between 0.1 and $1.5 \mathrm{t} \mathrm{ha}^{-1}$. Yields during the short rains are usually poor because the rain is unreliable, and there is little or no break between long-rain harvest and short-rain planting. This increases pest pressure, which in turn spreads the maize streak virus that reduces yields. In all rotations, maize production was roughly doubled by phosphorus fertilization, indicating significant phosphorus deficiency at this site. Maize grain yields reported from the same region by other authors have averaged about $1 \mathrm{tha} \mathrm{ha}^{-1}$ without and $2 \mathrm{t} \mathrm{ha}^{-1}$ with phosphorus fertilization (Maroko et al., 1999; Nziguheba et al., 2000; Kwabiah et al., 2003). This low productivity can be due to a variety of factors, such as limited water availability, deficiency in nutrients other than phosphorus, and weed, disease, and pest problems.

Cumulative maize production over 5.5 years did not differ significantly among the three rotations, indicating that the maize yield forgone during the fallow season was compensated for by higher postfallow yields (Figure 37.1). During the first fallow season, the Crotalaria fallow was more productive than the natural fallow, recycling $5.3 \mathrm{t}$ dry matter ha ${ }^{-1}$ compared with $3.2 \mathrm{t} \mathrm{ha}^{-1}$ for the natural fallow. The subsequent maize yield was doubled after the Crotalaria fallow at both levels of phosphorus fertilization. However, Crotalaria growth decreased during the course of the experiment due to pest problems, such as infestation with planthopper and subsequent colonization of stem lesions by saprophytic fungi (Girma, 2002). As a consequence, with longer duration, the introduced fallow was no longer beneficial for the subsequent maize crop compared with continuous maize, and at the end of the field experiment, the cumulative maize yield was similar between the three rotations (Figure 37.1).

\subsubsection{Soil Microbial Involvement in Crop-Fallow Systems}

In terms of changes in the soil system, both fallow types reversed the trend of soil organic matter depletion observed under continuous maize. The highest concentrations of soil organic matter and microbial nutrients were found in the maize-Crotalaria rotation, while plant-available soil phosphate concentrations were similar in all three rotations, being 


\section{TABLE 37.2}

Characteristics of Kenyan Oxisols Evaluated

\begin{tabular}{|c|c|c|c|c|c|c|c|c|c|}
\hline $\begin{array}{c}\text { Location and Grassland } \\
\text { Type }\end{array}$ & $\begin{array}{c}\text { Soil Type and } \\
\text { Texture }\end{array}$ & $\begin{array}{c}\text { Depth } \\
(\mathrm{cm})\end{array}$ & $\mathrm{pH}$ & $\begin{array}{c}\text { Organic C } \\
\left(\mathrm{g} \mathrm{kg}^{-1}\right)\end{array}$ & $\begin{array}{c}\text { Total P } \\
\left(\mathrm{mg} \mathrm{kg}^{-1}\right)\end{array}$ & $\begin{array}{r}\text { Organic P } \\
\left(\mathrm{mg} \mathrm{kg}^{-1}\right)\end{array}$ & $\begin{array}{l}\text { Microbial } \mathrm{P}^{\mathrm{a}} \\
\left(\mathrm{mg} \mathrm{kg}^{-1}\right)\end{array}$ & $\begin{array}{l}\text { Plant-Available P } \\
\left(\text { Resin-P) }\left(\mathrm{mg} \mathrm{kg}^{-1}\right)\right.\end{array}$ & Reference \\
\hline \multicolumn{10}{|l|}{$\begin{array}{l}\text { Maize cropping systems, zero } \\
\text { phosphorus treatment }\end{array}$} \\
\hline Continuous maize & Oxisol: & $0-15$ & 5.0 & 24.0 & 720 & 271 & 3.4 & 1.8 & Bünemann (2003), \\
\hline Weed fallow & $39 \%$ clay, & & 5.0 & 25.8 & 703 & 267 & 5.2 & 1.7 & Bünemann et al \\
\hline Crotalaria fallow & $37 \%$ sand & & 5.0 & 25.6 & 721 & 282 & 6.2 & 1.7 & $(2004 b)$ \\
\hline $\begin{array}{l}\text { Maize cropping systems, } \\
\text { fertilized treatment } \\
\left(50 \mathrm{~kg} \mathrm{P} \mathrm{ha}^{-1} \text { year }^{-1}\right)\end{array}$ & & & & & & & & & Same \\
\hline Continuous maize & Oxisol: & $0-15$ & 4.8 & 23.7 & 838 & 257 & 3.5 & 6.9 & \\
\hline Natural fallow & $39 \%$ clay, & & 5.1 & 25.2 & 837 & 278 & 5.4 & 6.7 & \\
\hline Crotalaria fallow & $37 \%$ sand & & 5.0 & 26.3 & 829 & 289 & 6.6 & 6.3 & \\
\hline
\end{tabular}

a All values present microbial phosphorus extracted after soil fumigation (i.e., no conversion factors ( $\left.k_{\mathrm{P}}\right)$ applied). 


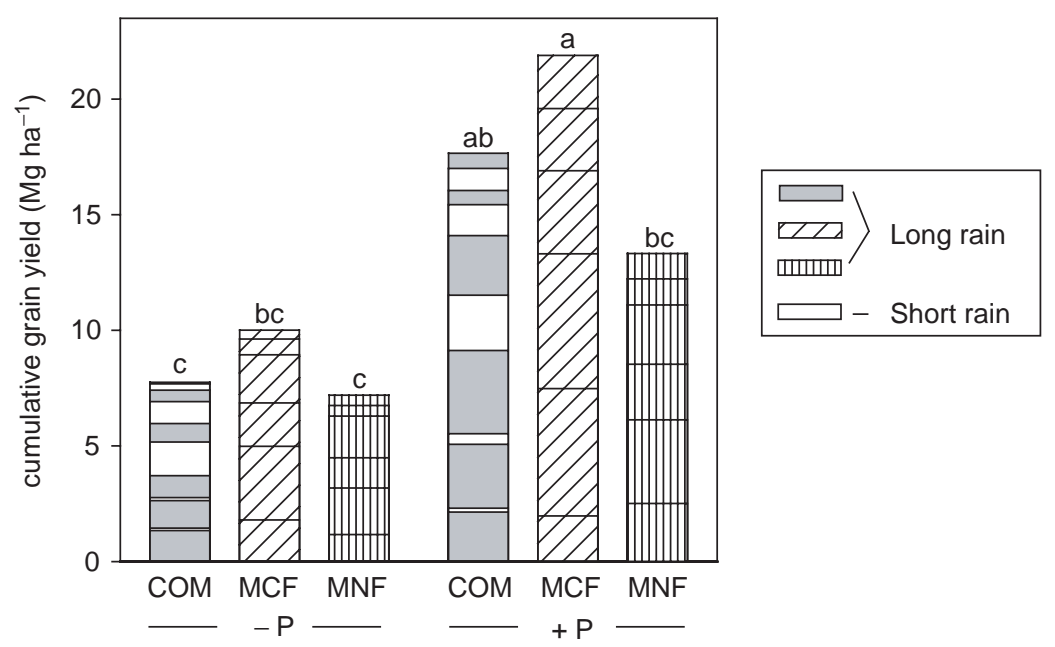

FIGURE 37.1

Cumulative maize grain yields during 5.5 years of field experimentation. COM, continuous maize; MCF, maize-crotalaria fallow, MNF, maize-natural fallow. Source: Authors' data.

significantly increased by phosphorus fertilization (Bünemann et al., 2004b) (Table 37.2). The composition of the microbial community, as indicated by phospholipid fatty acid analysis, differed somewhat between soils under continuous maize and in maizeCrotalaria rotation (Bünemann et al., 2004a). In particular, soils with greater microbial biomass concentrations contained a greater relative abundance of fungi and Gramnegative bacteria.

An incubation study with soils from this field experiment indicated that microorganisms took up phosphorus from stable pools in the soil following the addition of C. grahamiana residues labeled with radioactive phosphate (Bünemann et al., 2004c). Some incorporation of labeled phosphate into stable soil organic phosphorus supported the shift toward organic phosphorus observed in fallowed vs. monocropped soils. However, during the 9week incubation period, a large proportion of phosphorus from the residues remained in the microbial biomass. This prevented sorption of phosphorus to the soil matrix, but further work is needed to understand how microbial immobilization and remineralization cycles can be managed in order to render microbial phosphorus more available to field crops grown after fallow periods. Environmental alternations, such as drying and rewetting of soils, may solubilize phosphorus immobilized in the soil microbial biomass (Chapter 13).

The shift toward organic and microbial nutrients in maize-fallow rotations was also observed by Smestad et al. (2002), who measured increases in phosphorus contained in the soil microbial biomass, particulate soil organic matter, and stable soil organic phosphorus. The activation of native soil phosphorus by microbial uptake in response to organic matter addition to highly weathered soils has also been reported by Guppy (2003), but cannot be expected if total soil phosphorus contents are very low (Compaoré et al., 2003).

\subsubsection{Effects of Fallows on the Overall System}

Studies in southern Cameroon have observed no beneficial effect of Calliandra tree fallows on the yield of the main crops (Nolte et al., 2005). This indicated that short-term fallow plants, which provide an immediate benefit to the farmer, e.g., through the production of firewood, even if readily adopted can lead to substantial nutrient removal from the 
system (Nolte et al., 2003). Managed fallows may therefore lead to more negative phosphorus balances than those reported generally for sub-Saharan Africa (Smaling et al., 1997) if there are no corresponding phosphorus inputs (Bünemann et al., 2004b).

Problems arising from pests when fallow systems lack biodiversity were observed in other experiments as well as on farms (Drechsel et al., 1996; Smestad et al., 2002). Of particular concern is an increase in pathogenic nematodes (Desaeger and Rao, 2000). These examples demonstrate the need to test carefully the various biophysical effects of inserting particular fallow plants into cropping systems. They also confirm the value of participatory approaches to improve adoption by farmers. This does not diminish the value of systematic screening efforts that assess which of many leguminous species can, from a soil fertility standpoint, best serve as managed fallows (Niang et al., 2002).

Besides leguminous fallows, a nonleguminous shrub in the family Asteraceae, Tithonia diversifolia, has been widely tested as a fallow and green manure plant (Jama et al., 2000). It can improve phosphorus availability to crops through the acquisition of stable soil phosphorus, including organic phosphorus (George et al., 2002a), with subsequent rapid release of this phosphorus following residue amendment (Kwabiah et al., 2003). Being a nonlegume, it makes no net nutrient input of any element except carbon, although it may transfer nutrients from hedgerows or field boundaries onto arable areas (Jama et al., 2000).

\subsubsection{Implications of Experience from Western Kenya}

Short-term fallows have the potential to reverse soil organic matter depletion and to increase phosphorus held in the soil microbial biomass and in more stable soil organic phosphorus pools. They can mobilize phosphorus held in recalcitrant soil phosphorus pools through the effect of plant roots (George et al., 2002b) and enhanced microbial activity (Bünemann et al., 2004c). They may also reduce the phosphorus sorption capacity of soils during decomposition (Nziguheba et al., 1998).

It is noteworthy that these effects, which indicate enhanced soil organic phosphorus turnover, are not necessarily measurable as an increase in plant-available phosphate (next section). All these processes increase the availability of soil phosphorus, but must be complemented by balanced addition of mineral or organic fertilizer to prevent nutrient depletion of the soil (Smithson and Giller, 2002). Furthermore, attention has to be paid to the diversity of planted fallow species in order to avoid pest problems.

\subsection{Some Further Examples of Improved Soil Phosphorus Availability by Enhancing Soil Biological Activity}

The two experiences considered above focused on combining organic matter management with the use of selected germplasm and strategic inputs of low doses of phosphorus fertilizer. However, there are some good examples of similar improvements made by enhancing soil phosphorus availability through other kinds of biological interventions.

Planted tree or shrub fallows of Calliandra calothyrsus, Indigofera constricta, and T. diversifolia increased the amounts of carbon, nitrogen, and phosphorus in the sandsized soil organic matter in a volcanic-ash soil of the hillsides in southwestern Colombia (Phiri et al., 2001). Similarly, tree crops improved soil phosphorus availability to perennial crops in central Amazonian Oxisols (Lehmann et al., 2001). In the Amazon research reported in the preceding chapter, enhanced phosphorus cycling through the soil microbial biomass and between plants and soil meant that the need for phosphorus 
fertilizer application could be reduced to only as much as would replenish the phosphorus exported in harvested crops.

Agroforestry systems in Brazil have improved phosphorus availability in a shaded coffee cultivation system compared with the conventional unshaded system, apparently by promoting the turnover of organic phosphorus (Cardoso et al., 2003). In agroforestry production systems established on sandy savanna soils in Venezuela, the continued addition of animal manure improved soil physical and chemical characteristics and enhanced soil microbial activity (Lopez-Hernandez et al., 2004). Enhanced earthworm abundance was related to greater enzyme activities and microbial biomass. The concentrations of both inorganic and organic phosphorus in the soil were increased. Leguminous cover crops grown in the interspaces of coconut plantations have increased plant-available phosphorus and the rates of biochemical processes in a sandy clay-loam soil in a humid tropical region of India (Dinesh et al., 2004).

Soil microbiological and biochemical parameters were sensitive indicators of soil quality under managed fallow systems with herbaceous or shrubby legumes established on sites with varying degrees of soil degradation in southwestern Nigeria (Wick et al., 1998). In particular, changes in alkaline phosphatase activity can highlight interactions between organic phosphorus dynamics and overall soil fertility in tropical agroecosystems.

Greater soil microbial activity by itself may be beneficial only if the system is modified. Fire-free alternatives to smallholders' slash-and-burn agriculture have been evaluated in the eastern Amazon by Denich et al. (2004). In this region, a 2-year cropping period is alternated with 3 to 7 years of fallow, during which time a woody secondary-forest vegetation regenerates by resprouting from the roots. Traditional burning of fallow vegetation causes most of the carbon, nitrogen, and phosphorus stocks in the aboveground biomass to be lost by volatilization or ash-particle transfer (Sommer et al., 2004). In contrast, the use of mechanized chop-and-mulch technology for land preparation avoids the nutrient losses caused by burning, yet crops grown in the mulch layer do not immediately benefit. This occurs because the availability of nutrients, especially phosphorus, is reduced by microbial immobilization (Bünemann et al., 1998). This probably explains, at least in some cases, the lower yields in mulched compared with burned fields (Kato et al., 1999). With moderate quantities of NPK fertilizer, the first two crops (rice and cowpea) performed equally well in burned and mulched areas. Only the last crop of the sequence, cassava, did not require fertilizer to yield as well in mulched as in burned areas.

The change from burning to mulching certainly stimulates soil biological activity and preserves soil organic matter and associated nutrients. To be successful, however, there may need to be other modifications of the system. These can include selection of cultivars adapted to the more acidic surface soils in mulched as compared with burned areas, and inversion of the cropping sequence by planting first the crop with the lowest nutrient requirements. This cascade of required changes poses a challenge to farmers and researchers. The mulch system, compared with traditional burning, requires additional labor and changes in the cropping system as well as certain agronomic changes. However, it offers opportunities such as more flexible planting dates and an extended cropping phase that allows a maximization of benefits from the slowly decomposing mulch layer (Denich et al., 2004).

\subsection{Assessing and Improving Phosphorus Fertility in Tropical Soils}

Assessing the success of biological approaches to improving phosphorus availability in tropical soils remains a challenge. In current agricultural practice, phosphorus availability 
in soils is determined by measuring the size of a phosphate pool, for example, by extraction with bicarbonate (e.g., Olsen et al., 1954), by dilute mineral acid (e.g., Bray and Kurtz, 1945), or by anion exchange resins (Amer et al., 1955). Such "snapshot" measurements of phosphate availability are related empirically to observed crop growth using field experiments, and these relationships are then used to determine fertilizer requirements.

Such methods adapted and calibrated for the specific soil under study can provide relevant information on the amount of phosphate that is available to the plant in a tropical soil (Bühler et al., 2003). However, they do not provide information on the turnover of (organic) phosphorus, even though this is closely related to the actual phosphorus availability in tropical soils (Tiessen and Shang, 1998). In fact, a low extractable phosphate concentration may conceal a rapid rate of organic phosphorus turnover that contributes significantly to the supply of phosphorus to plants. This is apparent when conventionally managed farmland is first brought under organic cultivation (Oberson and Frossard, 2005).

The dependence of phosphorus fertility on organic matter turnover leads to feedback mechanisms that confound further the assessment of phosphorus availability in tropical soils by chemical tests. For example, if it is organic phosphorus turnover that regulates the availability of phosphate, then a decrease in the rate of turnover may place a nutrient limitation on organic matter decomposition. This, in turn, will constrain the turnover of organic phosphorus (Tiessen and Shang, 1998).

Such complexity means that phosphorus availability in tropical cropping systems based on organic matter inputs cannot be assessed accurately by conventional soil testing procedures. These were developed in industrialized countries of the temperate zone where mineral fertilizer is readily accessible to farmers, and the soils have generally less capacity to sorb phosphorus compared with those in many tropical regions. In temperate soils, a single measurement of extractable phosphate can yield results with some relevance to crop uptake, whereas in tropical soils there is a clear need also to assess continually the rates of phosphorus turnover (Organic Phosphorus Workshop, 2005). Unfortunately, there are currently no straightforward methods for assessing organic phosphorus turnover in tropical soils.

\subsection{Discussion}

Productivity of many tropical agricultural systems must be urgently increased to meet the needs of a growing and often malnourished world population. Phosphorus is a cropnutrient element that is fundamental in any attempt to achieve this objective because crop production in the tropics is so often limited by the availability of soil phosphorus. For most farmers in tropical regions, mineral phosphate fertilizer is an expensive and often inaccessible means of improving phosphorus fertility. The case studies from the eastern plains of Colombia and western Kenya show that biological interventions are available that are relatively simple and low cost and can improve phosphorus fertility in tropical agroecosystems. The common feature of these interventions is the input of organic matter into the soil, mainly through the residues from leguminous pasture or fallow plants that are adapted to low-phosphorus tropical soils.

The use of well-adapted germplasm together with low doses of phosphorus fertilizers can enhance system productivity, in turn adding to the supply of organic residues aboveand belowground. Phosphorus acquisition varies according to germplasm much as symbiotic nitrogen fixation does in legumes, with the quality as well as the amount of residues returned to the soil being important. Since organic matter boosts soil microbial 
activity, the microbiologically-driven processes in soil phosphorus dynamics are enhanced, and the microbial phosphorus pool is increased when greater amounts of organic matter are made available. Phosphorus recycles more efficiently among plants, microorganisms, and organic forms of phosphorus in the soil where it is protected from strong sorption in highly weathered tropical soils. Enhanced turnover can increase phosphorus availability for crops.

This said, the widespread adoption of biological interventions by farmers requires investments in germplasm, fertilizers, and knowledge of pasture and/or crop management techniques. Such investments, which must occur alongside an intensification and diversification of the overall farm operations, are made only when farmers perceive and expect tangible benefits from self-supply and when favorable markets for their produce are accessible. Finally, sustainable agricultural systems require that phosphorus inputs and outputs be in balance over the long term, in order to avoid an excessive depletion of soil phosphorus stocks.

\section{References}

Amer, F. et al., Characterisation of soil phosphorus by anion exchange resin adsorption and 32P equilibration, Plant Soil, 6, 391-408 (1955).

Bray, R.H. and Kurtz, L.T., Determination of total, organic and available forms of phosphorus in soils, Soil Sci., 59, 39-45 (1945).

Brossard, M., Lavelle, P., and Laurent, J.Y., Digestion of a vertisol by the endogeic earthworm Polypheretima elongata, Megascolecidae, increases soil phosphate extractability, Eur. J. Soil Biol., 32, 107-111 (1996).

Bühler, S. et al., Sequential phosphorus extraction of a P-33-labeled oxisol under contrasting agricultural systems, Soil Sci. Soc. Am. J., 66, 868-877 (2002).

Bühler, S. et al., Isotope methods for assessing plant available phosphorus in acid tropical soils, Eur. J. Soil Sci., 54, 605-616 (2003).

Bünemann, E., Phosphorus dynamics in a Ferralsol under maize-fallow rotations: The role of the soil microbial biomass. Ph.D. Thesis, Swiss Federal Institute of Technology, Zurich (2003). http:/ /e-collection.ethbib.ethz.ch/cgi-bin/show.pl?type = diss\&nr $=15207$.

Bünemann, E. et al., Fertilizer response of maize and cowpea under conditions of fire-free land preparation in NE Pará, In: Proceedings of the Third SHIFT-Workshop, Manaus, March 15-19, 1998, Lieberei, R., Voß, K., and Bianchi, H., Eds., BMBF/GKSS, Hamburg, 157-159 (1998).

Bünemann, E. et al., Microbial community composition and substrate use in a highly weathered soil as affected by crop rotation and P fertilization, Soil Biol. Biochem., 36, 889-901 (2004a).

Bünemann, E. et al., Maize productivity and nutrient dynamics in maize-fallow rotations in western Kenya, Plant Soil, 264, 195-208 (2004b).

Bünemann, E. et al., Phosphorus dynamics in a highly weathered soil as revealed by isotopic labeling techniques, Soil Sci. Soc. Am. J., 68, 1645-1655 (2004c).

Cardoso, I.M. et al., Analysis of phosphorus by (PNMR)-P-31 in Oxisols under agroforestry and conventional coffee systems in Brazil, Geoderma, 112, 51-70 (2003).

Chapuis-Lardy, L. et al., Phosphorus transformations in a ferralsol through ingestion by Pontoscolex corethrurus, a geophagous earthworm, Eur. J. Soil Biol., 34, 61-67 (1998).

Compaoré, E. et al., Influence of land-use management on isotopically exchangeable phosphate in soils from Burkina Faso, Commun. Soil Sci. Plant Anal., 34, 201-223 (2003).

Decaens, T. et al., Impact of land management on soil macrofauna in the Oriental Llanos of Colombia, Eur. J. Soil Biol., 30, 157-168 (1994).

Denich, M. et al., Mechanized land preparation in forest-based fallow systems: The experience from Eastern Amazonia, Agroforest. Syst., 61, 91-106 (2004). 
Desaeger, J. and Rao, M.R., Parasitic nematode populations in natural fallows and improved cover crops and their effects on subsequent crops in Kenya, Field Crops Res., 65, 41-56 (2000).

Dinesh, R. et al., Long-term influence of leguminous cover crops on the biochemical properties of a sandy clay loam Fluventic Sulfaquent in a humid tropical region of India, Soil Till. Res., 77, 69-77 (2004).

Drechsel, P., Steiner, K.G., and Hagedorn, F., A review on the potential of improved fallows and green manure in Rwanda, Agroforest. Syst., 33, 109-136 (1996).

Friesen, D.K. et al., Phosphorus acquisition and cycling in crop and pasture systems in low fertility tropical soils, Plant Soil, 196, 289-294 (1997).

Gathumbi, S.M., Cadisch, G., and Giller, K.E., N-15 natural abundance as a tool for assessing $\mathrm{N}-2$-fixation of herbaceous, shrub and tree legumes in improved fallows, Soil Biol. Biochem., 34, 1059-1071 (2002).

George, T.S. et al., Changes in phosphorus concentrations and $\mathrm{pH}$ in the rhizosphere of some agroforestry and crop species, Plant Soil, 246, 65-73 (2002a).

George, T.S. et al., Utilisation of soil organic P by agroforestry and crop species in the field, western Kenya, Plant Soil, 246, 53-63 (2002b).

Gijsman, A.J., Alcaron, H.F., and Thomas, R.T., Root decomposition in tropical grasses and legumes, as affected by soil texture and season, Soil Biol. Biochem., 29, 1443-1450 (1997a).

Gijsman, A.J. et al., Nutrient cycling through microbial biomass under rice-pasture rotations replacing native savanna, Soil Biol. Biochem., 29, 1433-1441 (1997b).

Girma, H., Insect pest problems and their management in planted fallow crop rotation in western Kenya. Ph.D. Thesis, Kenyatta University, Nairobi, Kenya (2002).

Guggenberger, G. et al., Assessing the organic phosphorus status of an Oxisol under tropical pastures following native savanna using 31P NMR spectroscopy, Biol. Fertil. Soils, 23, 332-339 (1996).

Guimaráes, E.P. et al., Research on agropastoral systems: What we have learned and what we should do, In: Agropastoral Systems for the Tropical Savannas of Latin America, Guimaráes, E.P. et al., Eds., CIAT/EMBRAPA, Cali, Colombia/Brazil, 326-336 (2004).

Guppy, C.N., Phosphorus and organic matter interactions in highly weathered soils. Ph.D. Thesis, University of Queensland, Australia (2003).

Hartemink, A.E. et al., Soil nitrate and water dynamics in sesbania fallows, weed fallows and maize, Soil Sci. Soc. Am. J., 60, 568-574 (1996).

Jama, B., Swinkels, R.A., and Buresh, R.J., Agronomic and economic evaluation of organic and inorganic sources of phosphorus in Western Kenya, Agron. J., 89, 597-604 (1997).

Jama, B. et al., Tithonia diversifolia as a green manure for soil fertility improvement in western Kenya: A review, Agroforest. Syst., 49, 201-221 (2000).

Jiménez, J.J. and Decaens, T., The impact of soil organisms on soil functioning under neotropical pastures: A case study of a tropical anecic earthworm species, Agric. Ecosyst. Environ., 103, 329-342 (2004).

Jiménez, J.J. et al., Phosphorus fractions and dynamics in surface earthworm casts under native and improved grasslands in a Colombian savanna oxisol, Soil Biol. Biochem., 35, 715-727 (2003).

Kato, M.S.A. et al., Fire-free alternatives to slash-and-burn for shifting cultivation in the eastern Amazon region: The role of fertilizers, Field Crops Res., 62, 225-237 (1999).

Kwabiah, A.B. et al., Phosphorus availability and maize response to organic and inorganic fertilizer inputs in a short term study in western Kenya, Agric. Ecosyst. Environ., 95, 49-59 (2003).

Lascano, C. and Estrada, J., Long-term productivity of legume-based and pure grass pastures in the eastern plains of Colombia, Proceedings of the XVI International Grassland Conference, Nice, France, 1179-1180 (1989).

Lehmann, J. et al., Phosphorus management for perennial crops in central Amazonian upland soils, Plant Soil, 237, 309-319 (2001).

Lopez-Hernandez, D. et al., Changes in soil properties and earthworm populations induced by longterm organic fertilization of a sandy soil in the Venezuelan Amazonia, Soil Sci., 169, 188-194 (2004). 
Maroko, J.B., Buresh, R.J., and Smithson, P.C., Soil phosphorus fractions in unfertilized fallow-maize systems on two tropical soils, Soil Sci. Soc. Am. J., 63, 320-326 (1999).

Merckx, R., den Hartog, A., and Van Veen, J.A., Turnover of root-derived material and related microbial biomass formation in soils of different texture, Soil Biol. Biochem., 17, 565-569 (1985).

Niang, A.I. et al., Species screening for short-term planted fallows in the highlands of western Kenya, Agroforest. Syst., 56, 145-154 (2002).

Nolte, C. et al., Effects of Calliandra planting pattern on biomass production and nutrient accumulation in planted fallows of southern Cameroon, Forest Ecol. Manage., 179, 535-545 (2003).

Nolte, C. et al., Groundnut, maize and cassava yields in mixed-food crops fields after Calliandra tree fallow in southern Cameroon, Exp. Agric., 41, 21-37 (2005).

Nziguheba, G. and Bünemann, E., Organic phosphorus dynamics in tropical agroecosystems, In: Organic Phosphorus in the Environment, Turner, B.L., Frossard, E., and Baldwin, D.S., Eds., CAB International, Wallingford, UK, 243-268 (2005).

Nziguheba, G. et al., Organic residues affect phosphorus availability and maize yields in a Nitisol of western Kenya, Biol. Fertil. Soils, 32, 328-339 (2000).

Nziguheba, G. et al., Soil phosphorus fractions and adsorption as affected by organic and inorganic sources, Plant Soil, 198, 159-168 (1998).

Oberson, A. and Frossard, E., Phosphorus management for organic agriculture, In: Phosphorus: Agriculture and the Environment, Sims, J.T. and Sharpley, A.N., Eds., ASA, CSSA and SSSA, Madison, WI, 761-779 (2005).

Oberson, A. and Joner, E.J., Microbial turnover of phosphorus in soil, In: Organic Phosphorus in the Environment, Turner, B.L., Frossard, E., and Baldwin, D.S., Eds., CAB International, Wallingford, UK, 133-164 (2005).

Oberson, A. et al., Phosphorus status and cycling in native savanna and improved pastures on an acid low-P Colombian Oxisol, Nutr. Cycl. Agroecosyst., 55, 77-88 (1999).

Oberson, A. et al., Phosphorus transformations in an Oxisol under contrasting land-use systems: The role of the soil microbial biomass, Plant Soil, 237, 197-210 (2001).

Olsen, S.R. et al., Estimation of Available Phosphorus in Soils by Extraction with Sodium Bicarbonate, United States Department of Agriculture, Washington, DC (1954).

Organic Phosphorus Workshop, Synthesis and recommendations for future research, In: Organic Phosphorus in the Environment, Turner, B.L., Frosssard, E., and Baldwin, D.S., Eds., CAB International, Wallingford, UK, 377-380 (2005).

Phiri, S. et al., Changes in soil organic matter and phosphorus fractions under planted fallows and a crop rotation system on a Colombian volcanic-ash soil, Plant Soil, 231, 211-223 (2001).

Phiri, S. et al., Constructing an arable layer through chisel tillage and agropastoral systems in tropical savanna soils of the llanos of Colombia, J. Sustain. Agric., 23, 5-29 (2003).

Rao, I.M., Plazas, C., and Ricaurte, J., Root turnover and nutrient cycling in native and introduced pastures in tropical savannas, In: Plant Nutrition: Food Security and Sustainability of AgroEcosystems through Basic and Applied Research, Horst, W.J. et al., Eds., Kluwer Academic Publishers, Dordrecht, Netherlands, 976-977 (2001).

Rao, I.M. et al., Adaptive attributes of tropical forage species to acid soils I. Differences in shoot and root growth responses to varying phosphorus supply and soil type, J. Plant Nutr., 19, 323-352 (1996).

Rao, I.M. et al., Soil phosphorus dynamics, acquisition and cycling in crop-pasture-fallow systems in low fertility tropical soils of Latin America, In: Modelling Nutrient Management in Tropical Cropping Systems, Delve, R.J. and Probert, M.E., Eds., Australian Center for International Agricultural Research (ACIAR), Canberra, Australia, 126-134 (2004).

Sanchez, P.A., Improved fallows come of age in the tropics, Agroforest. Syst., 47, 3-12 (1999).

Sieverding, E., Vesicular-Arbuscular Mycorrhiza Management in Tropical Agrosystems. Deutsche Gesellschaft für Technische Zusammenarbeit, Eschborn, Germany (1991).

Smaling, E.M.A., Nandwa, S.M., and Janssen, B.H., Soil fertility in Africa is at stake, In: Replenishing Soil Fertility in Africa, Buresh, R.J., Sanchez, P.A., and Calhoun, F., Eds., Soil Science Society of America and American Society of Agronomy, Madison, WI, 47-61 (1997). 
Smestad, T.B., Tiessen, H., and Buresh, R.J., Short fallows of Tithonia diversifolia and Crotalaria grahamiana for soil fertility improvement in western Kenya, Agroforest. Syst., 55, 181-194 (2002).

Smithson, P.C. and Giller, K.E., Appropriate farm management practices for alleviating $\mathrm{N}$ and P deficiencies in low-nutrient soils of the tropics, Plant Soil, 245, 169-180 (2002).

Sommer, R. et al., Nutrient balance of shifting cultivation by burning or mulching in the Eastern Amazon: Evidence for subsoil nutrient accumulation, Nutr. Cycl. Agroecosyst., 68, 257-271 (2004).

Thomas, R.J., The role of the legume in the nitrogen cycle of productive and sustainable pastures, Grass Forage Sci., 47, 133-142 (1992).

Thomas, R.J. et al., Nutrient cycling via forage litter in tropical grass/legume pastures. In: XVII International Grassland Congress, Hodgson J, Ed., NZGA, TGSA, NZSAP, ASAP-Qld. and NZIAS, Palmerston North, New Zealand, 508-509 (1993).

Tiessen, H. and Shang, C., Organic matter turnover in tropical land use systems, In: Carbon and Nutrient Dynamics in Natural and Agricultural Tropical Ecosystems, Bergström, L. and Kirchmann, H., Eds., CAB International, Wallingford, UK, 1-14 (1998).

Wick, B., Kühne, R.F., and Vlek, P.L.G., Soil microbiological parameters as indicators of soil quality under improved fallow management systems in south-western Nigeria, Plant Soil, 202, 97-107 (1998). 


\section{Author Query}

JOB NUMBER: BK 12237

TITLE: Improving Phosphorus Fertility in Tropical Soils

Q1 Please provide city for affiliations "CIMMYT", "CIAT", Berea College \& Smithsonian Tropical Research Institute. 